This item was submitted to Loughborough's Research Repository by the author.

Items in Figshare are protected by copyright, with all rights reserved, unless otherwise indicated.

\title{
RoMEO Studies 4: an analysis of Journal Publishers' Copyright Agreements
}

PLEASE CITE THE PUBLISHED VERSION

PUBLISHER

Association of Learned and Professional Society Publishers

LICENCE

CC BY-NC-ND 4.0

\section{REPOSITORY RECORD}

Gadd, Elizabeth A., Charles Oppenheim, and Steve Probets. 2019. "Romeo Studies 4: An Analysis of Journal Publishers' Copyright Agreements". figshare. https://hdl.handle.net/2134/282. 


\title{
RoMEO Studies 4: An analysis of Journal Publishers' Copyright Agreements
}

Elizabeth Gadd, Charles Oppenheim, and Steve Probets

Department of Information Science, Loughborough University, Loughborough, Leics, LE11 3 TU

Email: C.Oppenheim@,lboro.ac.uk

This article has been accepted for publication in Learned Publishing, 16(4) October 2003.

\begin{abstract}
This article is the fourth in a series of six emanating from the UK JISC-funded RoMEO Project (Rights Metadata for Open archiving). It describes an analysis of 80 scholarly journal publishers' copyright agreements with a particular view to their effect on author self-archiving. $90 \%$ of agreements asked for copyright transfer and 69\% asked for it prior to refereeing the paper. $75 \%$ asked authors to warrant that their work had not been previously published although only two explicitly stated that they viewed self-archiving as prior publication. $28.5 \%$ of agreements provided authors with no usage rights over their own paper. Although $42.5 \%$ allowed self-archiving in some format, there was no consensus on the conditions under which self-archiving could take place. The article concludes that author-publisher copyright agreements should be reconsidered by a working party representing the needs of both parties.
\end{abstract}

\section{Introduction}

"The relationship between author and publisher is a partnership". So concludes the Publishers Licensing Society's Principles of good practice in scholarly journal publishing ${ }^{1}$. The characteristics of this partnership are documented to a great extent by the agreements Journal Publishers ask authors to sign on submitting their work for publication. Such agreements are written by publishers and have rarely been challenged by authors ${ }^{2}$. However, the 1999 ALPSP survey What authors want, found that " $61 \%$ of respondents thought that copyright should remain with the author, rather than being signed over to the publisher. ${ }^{3 \text { "' }}$ Project RoMEO's 2003 academic author survey found that $49 \%$ assigned copyright to publishers reluctantly ${ }^{4}$.

This increasing desire of scholarly authors to retain their rights may be due in part to their wish to reuse their own work - in particular, to "self-archive" it on a freely-available web site. The 2002 ALPSP survey, Authors and electronic publishing, found that $59 \%$ of authors considered the willingness of the publisher to permit self-archiving of a postprint online as either very important or important to them when selecting a publisher ${ }^{5}$. However, surveys of self-archivers show that two of their key concerns are that self-archiving works will break existing agreements with publishers, or that publishers will refuse to publish their work if they know it has been self-archived.

The UK JISC-funded RoMEO (Rights Metadata for Open archiving) Project ${ }^{6}$ has been tasked with considering the IPR issues relating to the self-archiving of academics' research papers. In order to prove the validity, or otherwise, of authors' fears, it was decided to perform an analysis of journal publishers' copyright agreements (CAs).

\section{Methods adopted}

Two complementary approaches were taken in order to select journal publishers for the CA analysis: a targeted approach; and a self-selecting approach. It was important that the project focused on publishers of high-impact, refereed academic journals as opposed to popular titles. The pressure to publish in quality journals is considerable amongst academics for reasons of promotion and tenure, and in the UK, for a good Research Assessment Exercise (RAE) rating ${ }^{7}$. A target list of publishers was drawn from: 
- The top 50 journals by impact factor in ISI's Journal Citation Reports (JCR) Science Citation Index (SCI) and Social Science Citation Index (SSCI) editions for 2001;

- The top 53 journal publishers by the number of academic refereed titles, as kindly supplied by Ulrichs Periodicals Directory;

- The top 20 STM journal publishers by the number of ISI-rated titles they owned, as taken from The UK Office for Fair Trading report into the market for STM journals ${ }^{8}$.

The resulting list, after removal of duplicates (and merged publishers) amounted to 84 journal publishers. Contact details for all 84 were identified and an email advertising the project and asking for copies of copyright agreements or licences was sent out to each. In addition to the targeted approach, it was decided to send out a general call for agreements via two professional bodies for academic journal publishers: the Association of Learned and Professional Society Publishers ${ }^{9}$ in the UK, and the Society for Scholarly Publishing ${ }^{10}$ in the US.

Agreements were collected between August and December 2002. Of the target group, five publishers refused to send copies of their agreements without explanation. One said their agreement was confidential, two said their agreements were under review, and two stated that they were simply unwilling to participate. Twenty-six did not respond at all.

An initial examination of a small number of the agreements was undertaken and a list of criteria against which all agreements would be analysed was developed (see Appendix A). The analysis fell into eleven categories:

- What rights were assigned (the assignment statement itself);

- Whether the publisher provided a licence option in addition to, or instead of, copyright assignment;

- Whether the publisher provided an option for employers that retain copyright, or for government-owned works;

- Whether the publisher specified why they require copyright assignment or licence;

- What rights were retained by the author? (e.g., moral rights);

- When were the rights assigned? (pre- or post- refereeing);

- What the author had to warrant;

- What the author was allowed to do with their own work;

- Conditions applying to the above exceptions;

- Conditions specifically applying to self-archiving;

- What the publisher would do in return for the rights granted by the author.

Where a publisher had different agreements for different journals, an agreement from a high-impact journal was taken where possible for analysis. If a publisher had a general agreement for a group of journals, and specific agreements for others, the general agreement was used for this analysis.

Our analysis is based only on what was explicitly written in the agreement documents. This is an important point to remember when reading the results. CAs, whilst representing the legal contract between the two parties, do not paint the whole picture of the author-publisher relationship.

\section{Response}

In total, 48 agreements were collected from the target group of 84 publishers. This was a response rate of $57.1 \%$. Of the 48,29 were publishers of the top 100 ISI journals by impact factor. Seventeen 
of the top 20 publishers of the largest numbers of ISI-rated titles were represented, and 21 were on the Ulrich's list of the 53 publishers of the largest numbers of academic refereed titles generally. This doesn't add up to 48 because some publishers were in more than one category. Between them, the target group of respondents published 6,960 academic journal titles ${ }^{11}$. A further 32 agreements were collected from other sources (e.g., the ALPSP mailing), representing a further 342 titles. A total of 80 agreements are therefore included in this analysis. The publishers represented collectively published 7,302 journal titles. According to the Ulrich's International Periodicals Directory, there are 39,318 active academic journal titles currently extant (17,556 of which are refereed), so the titles covered by agreements in this survey amount to $18.5 \%$ of these.

Of the 80 publishers, 41 had their headquarters in the US (51.2\%) and 30 were based in the UK $(37.5 \%)$. Of the remaining nine, three were based in the Netherlands, three in Germany, one each in Denmark and Holland, and one was unclear. In terms of publisher type, it was agreed with publisher members on the Project Advisory Board that 42 publishers could be classed as Learned Societies (52.5\%), $29(36.2 \%)$ as Commercial, and nine as University Presses. The number of titles published by the 80 publishers represented by this analysis are illustrated in Figure 1.

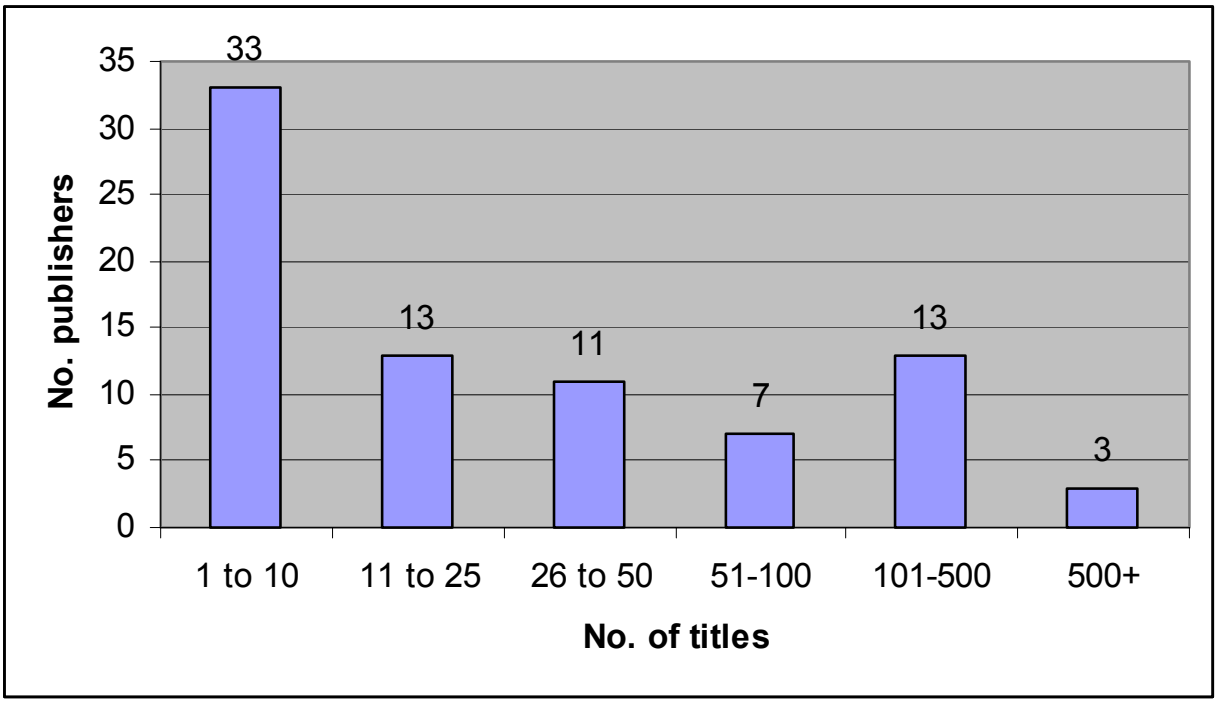

Figure 1 Number of titles published by represented publishers

\section{Copyright assignment or licensing}

In a guest editorial for Learned Publishing, Sally Morris wrote, "it is...hard to find a justification, other than convenience, for insisting on taking the author's copyright ${ }^{12}$." However, 72 of the 80 agreements (90\%), representing $94 \%$ of the journal titles, asked authors for copyright assignment, although four of these ( $2.4 \%$ of titles) gave authors the option of signing an exclusive licence agreement instead. Five of the remaining eight just asked for an exclusive licence $(4.9 \%$ of journal titles) and left 'copyright' with the author or copyright holder. This trend towards exclusive licences may have been in response to authors' increasing interest in retaining copyright. Indeed, the ALPSP itself has developed a Model Grant of Licence ${ }^{13}$ that it is promoting to its members. Three asked only for a non-exclusive licence ( $0.9 \%$ of titles). 


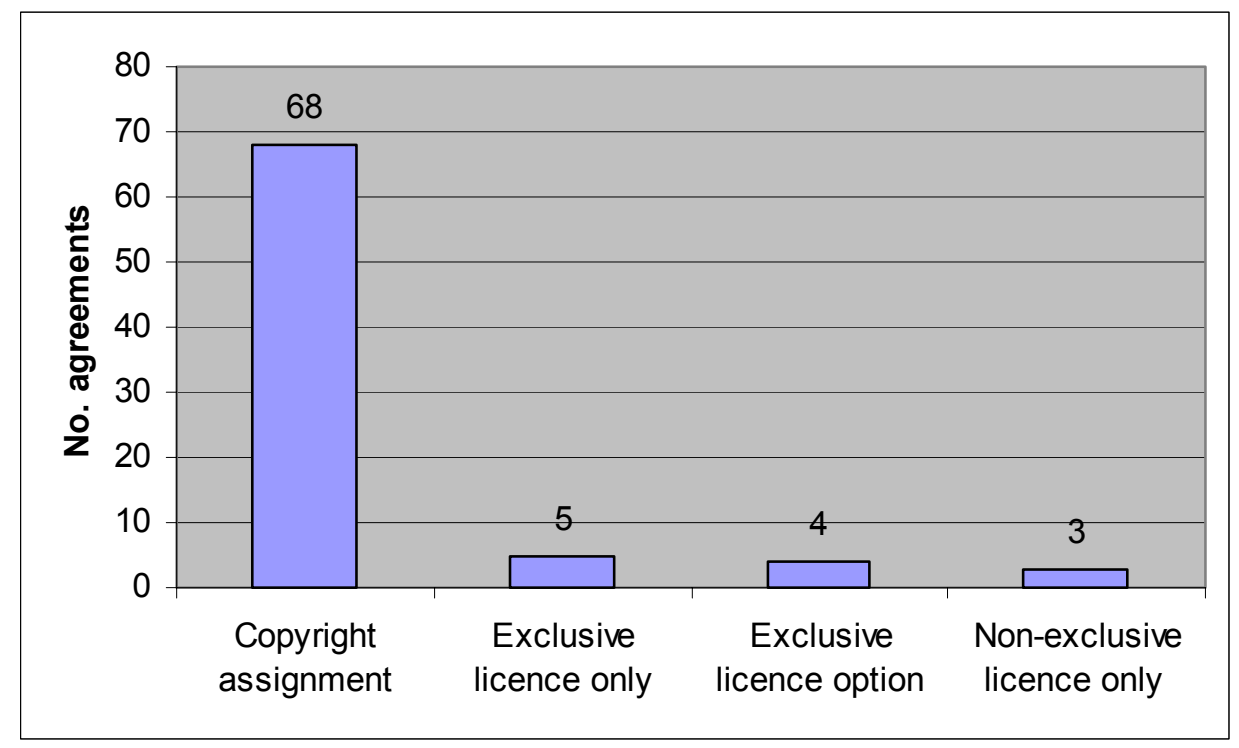

Figure 2 Copyright assignment vs copyright licences

The statements used by which authors assigned copyright varied from long exhaustive clauses through to single phrases such as "I/we hereby assign to [Publisher Name], full copyright in all formats and media in the said contribution".

The clauses by which authors were asked to grant exclusive licences to publishers were no less lengthy or exhaustive in the rights they required. This may have been because publishers asking for exclusive licences have to spell out exactly what rights they need to perform their business. In contrast, publishers that have had copyright assigned to them have their rights spelled out by copyright law.

Three agreements explicitly stated that substitute forms or amendments to the agreement document were unacceptable. In some cases, such forms would be rejected out of hand; if they were not, the resultant negotiation would understandably slow down the publication process.

The remainder of this analysis covers all agreements whether for copyright assignment or licensing of publication rights in the article.

\section{Reasons for requiring copyright agreements}

Thirty-six of the agreements (45\%) gave an explanation why copyright assignment or licence was required. Nineteen gave no specific reasons, but did include in their copyright assignment or licence statement wording to the effect that copyright was being granted 'in consideration of' reviewing and/or editing and/or publication. A 'consideration' is an essential element of any contract detailing what is given in return for the goods or services being provided. The remaining $25(31.2 \%)$ gave no explanation at all.

The main reasons given by those offering an explanation are illustrated in Figure 3. 


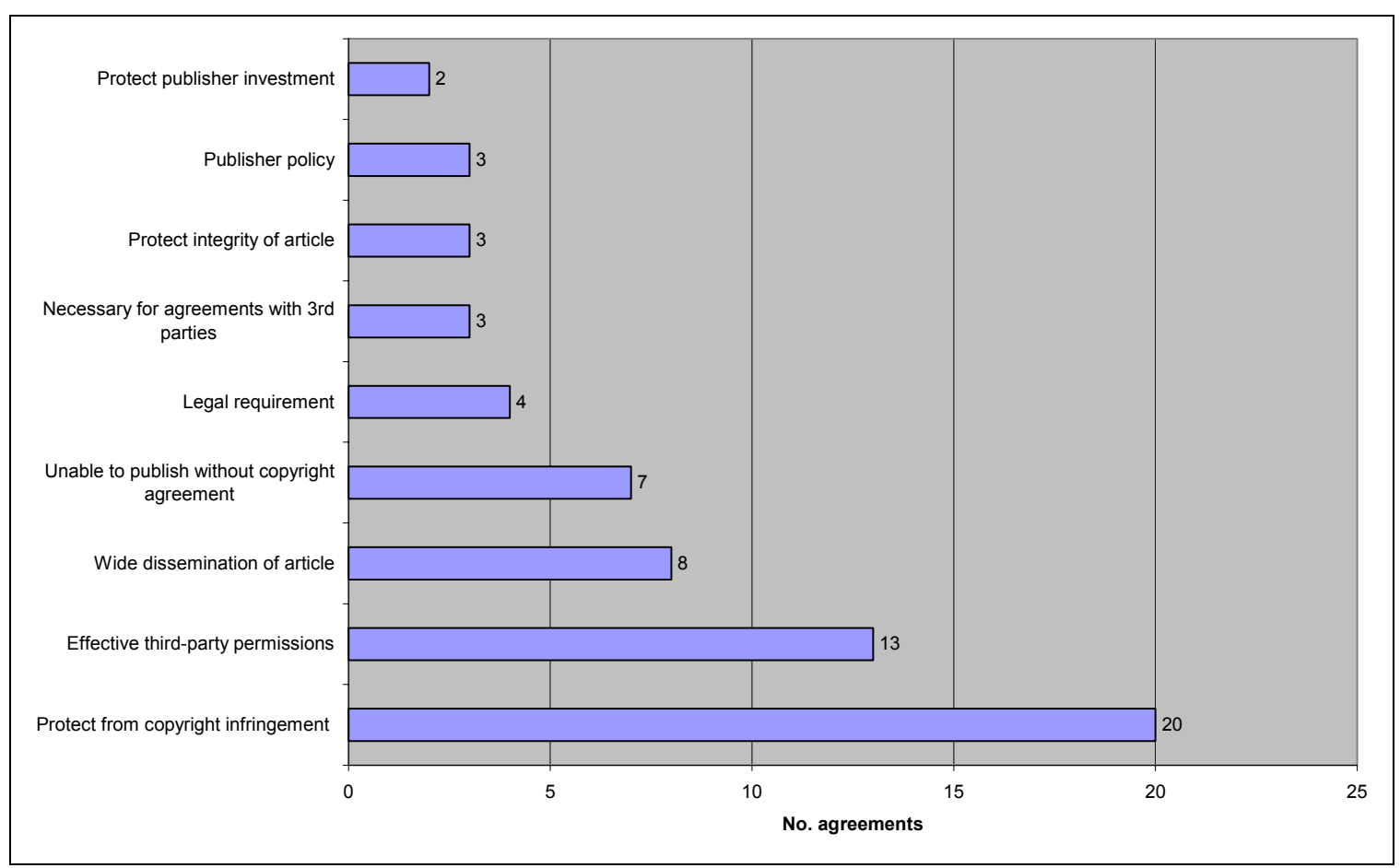

Figure 3 Reasons for requiring a copyright agreement

The most common explanation was that copyright transfer protected the author (and publisher) against copyright infringement. However, none explained how they did this ${ }^{14}$. Examples of copyright infringement included plagiarism, libel and unauthorized uses. A further three agreements said that copyright ownership by the publisher would protect the integrity of the article.

Effective and speedy third-party permissions management was the second-most popular explanation. A further three agreements said they needed copyright to manage arrangements with other thirdparties such as the Copyright Clearance Center and full-text database providers. This is indeed a benefit to both authors and permission-seekers in the current publishing model, saving the latter from having to locate the former, and saving the former from being bothered by the latter. However, if the whole model is short-circuited by authors making their papers freely available on the web (perhaps under explicit terms and conditions supplied by rights metadata), then permission no longer needs to be sought; ergo, the permission process would need no facilitation.

The promise of wide dissemination of the article was the third most common explanation. However, as Lawrence has shown, "articles freely available online are more highly cited" 15 . As CAs often prohibit the making of articles freely available online, it seems ironic that they claim to improve dissemination. It is, however, worth noting that Lawrence's study did not consider the effect on citation counts of having to pay for online access.

Seven publishers simply stated that they were "unable to publish" the article without copyright assignment but did not explain why. Three others asserted that it was "publisher policy" to get copyright assignment, but again gave no reasons. Four stated that it was a requirement of US law that "the transfer of copyright should be explicitly stated in writing to enable the publisher to publish and disseminate the work". (Actually, although Section 204(a) of the US Copyright Law states that, "A transfer of copyright ownership... is not valid unless... it is in writing ${ }^{16 "}$, it does not state that publishers have a legal requirement to obtain copyright transfer before they can publish. It only states that if copyright transfer does take place, it must be in writing.) Two also stated that the agreement allowed publishers to protect their investment in the publishing process. 
One question must be asked of those that simply prefixed their copyright assignment statement with a clause along the lines of, 'in consideration of [reviewing, editing and/or publication], I hereby assign copyright...'. That is, is copyright assignment an appropriate price to pay for reviewing, editing or publishing a work? Some publishers are prepared to do those things in return for a nonexclusive licence. Whether it is appropriate or not is perhaps irrelevant if authors are in fact willing to pay. They clearly are. The RoMEO author survey showed that $41 \%$ of respondents assigned copyright 'freely' in exchange for publication. However, other models - such as the author-pays mode ${ }^{17}$ - are currently being investigated and may provide a viable alternative to the author-payswith-copyright model.

\section{Employer ownership}

In certain circumstances, authors will not be in a position to assign copyright to journal publishers. Copyright in work produced by employees as part of their employment (known as 'work-for-hire' in the US) may belong to the employer. Also, in some countries, work produced by government employees is governed by different copyright rules. For example, in the US, government-owned works automatically belong in the public domain and are not protected by copyright.

\section{'Work-for-hire'}

Forty-four agreements (55\%) representing $72.1 \%$ of journal titles, explicitly made provision for copyright works owned by an employer (other than government-owned works). Twelve of these gave employers more liberal terms than authors were offered either by asking employers only for a non-exclusive licence, or by offering them more exceptions to use the work than authors were offered. This provides some motivation for universities to assert their copyright ownership in academics' research papers. Even where agreements ask employers to accept the same terms as authors, an employer may carry more weight in any negotiation process than an individual author. In the 32 other agreements where work-for-hire provisions were made, the employer simply had to sign either instead of, or as well as, the employee.

\section{Government-owned works}

Forty-six agreements explicitly gave options for US government owned works and 17 for crown copyright. Manuscripts belonging to the US government are, by definition, in the public domain (at least in the USA). This indicates that the majority of publishers are in fact willing and able to support a dual publication system where results are both in the public domain and published in a peer-reviewed journal.

\section{Time of assignment or licence}

The agreements were analysed to see whether publishers tended to ask for copyright transfer or licence prior to the refereeing process, or after the contribution had been accepted for publication (pre-refereeing and post-refereeing in Figure 4). In nine cases this was unclear. However, it was possible by the wording of the remaining agreements to ascertain when the authors were expected to sign. 


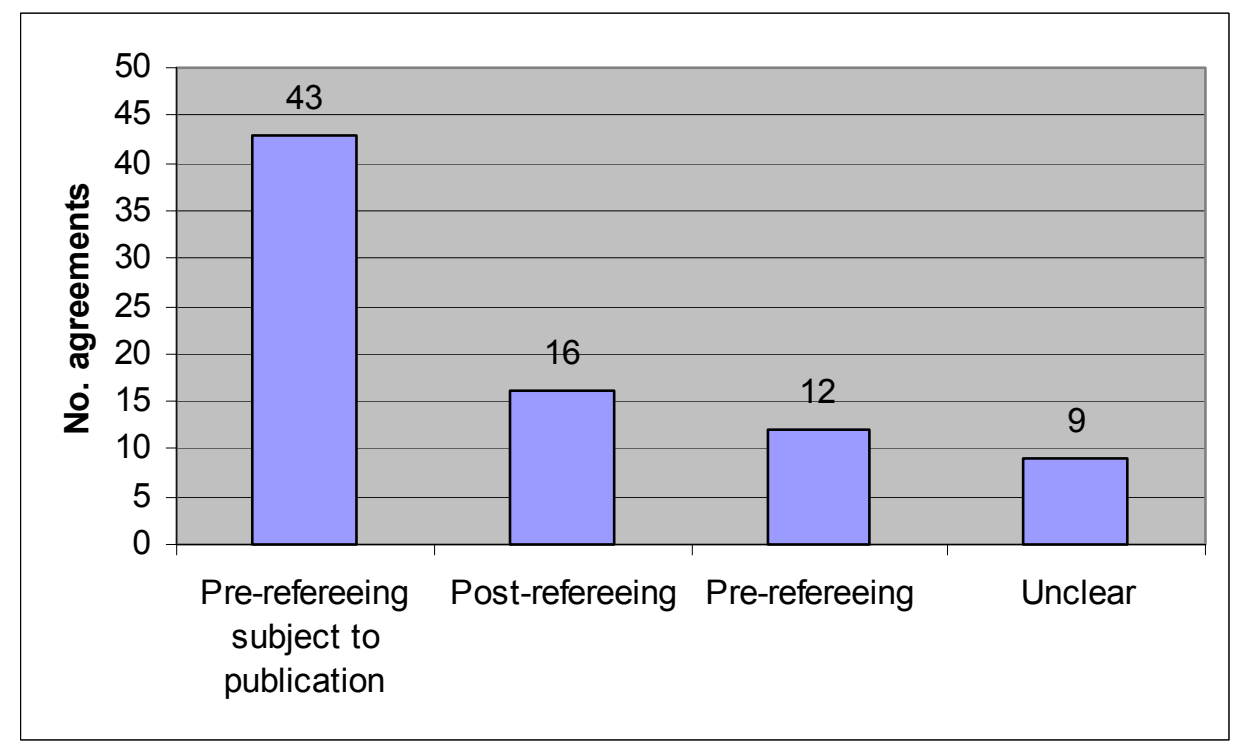

Figure 4 When the rights are assigned or licensed

In the majority of cases (53.7\% of CA's representing $79.5 \%$ of journal titles), authors were asked to assign copyright prior to the refereeing process but assignment was subject to the paper actually being accepted for publication. Worryingly, there was a small number of cases $(15 \%$ representing $10.8 \%$ of titles) where authors were asked to assign copyright prior to refereeing, but there was no mention of copyright reverting to the author if the paper was rejected. If literally true, this would mean that the author would then be unable to offer his/her paper to an alternative journal. In $20 \%$ of agreements authors assigned copyright post-refereeing, once the paper had been accepted for publication.

The time of copyright assignment has a significant effect on the self-archiving process. Once authors have assigned their copyright in the unrefereed preprint of their article, they cannot make it available without the publisher's permission. However, the Harnad-Oppenheim $(\mathrm{H}-\mathrm{O})$ proposal ${ }^{18}$, argues that if a work is self-archived prior to copyright assignment, then the preprint does not infringe the terms of the CA because at the time of self-archiving, the copyright belonged to the author. The H-O proposal depends upon the date of copyright assignment to protect all activities performed prior to it. Of course, the publisher may refuse to publish the article knowing it has previously been communicated to the public (the Ingelfinger rule), or may make its removal a condition of publication, but the fact remains that the original act of self-archiving was not an infringing one.

In cases where copyright assignment is only required after refereeing, authors have more time in which to self-archive their work, as they hold onto their copyright for much longer. The author could even legally publish the post-refereed version if they implement the referees' changes prior to signing the copyright transfer. However, again, they may have problems with the Ingelfinger rule adopted by most agreements.

\section{Pre- and post-prints: separate copyright works?}

An important issue relating to the time of assignment is whether the preprint and the postprint are actually separate copyright works. If they are, publishers requiring copyright transfer pre-refereeing may only have obtained rights in the preprint, and the author is free to do what s/he likes with the postprint. Publishers requiring transfer post-refereeing have the opposite problem. Only one agreement addressed the question of when a work becomes a new work. It read, 
...authors may revise their [Publisher]-copyrighted work and post the new version on non[Publisher] servers...If the new version differs by $25 \%$ or more from the copyrighted version, it is treated as a new work not copyrighted by [Publisher]; otherwise it is treated as a revision and is still copyrighted by [Publisher].

According to these rules, most refereed works would not constitute a separate work as they would not usually differ by $25 \%$ from the pre-refereed version. UK copyright law states that copyright is infringed if the copy is 'substantially' the same as the original. Assuming the preprint and post-print are substantially the same, posting one after assigning rights in the other would be considered an infringing act. Kahin has considered this issue from a US perspective and concluded that a different copyright actually rests in each draft. Thus, "If copyright in [the] final version is assigned to the publisher, the earlier versions are not necessarily assigned, so the author can take the prior version and adapt it into derivative works. ${ }^{19,}$

To pre-empt this problem, one agreement asked for copyright in both the work and in "any prior versions thereof". Another agreement obtained rights in the preprint but also asserted copyright in subsequent 'revisions and versions' of the work.

One further question is who owns the copyright in a revised paper. If the revisions are the result of referees' comments, there is an argument that copyright may be jointly owned by the original author and the referee. This argument is strengthened if the referee suggests wording which the author then adopts. We are not aware of any analysis of this interesting question. Referees themselves appear to have little interest in claiming a share of copyright in the final article, so perhaps it is a topic not worthy of study.

\section{Moral rights}

The protection of an author's moral rights is rooted in the European "droit d'auteur" tradition of copyright law. This views copyright as a means of protecting authors' interests and not as a means of economic gain as with the Anglo-Saxon tradition. Moral rights were only introduced in UK copyright law with the 1988 Act, and are not explicitly covered in US law at all. (It is argued that such rights are covered by other US legislation ${ }^{20}$ ). In the UK, moral rights include the right of 'paternity', namely, to be attributed as the author of a work, and the right of 'integrity', namely the right to object to derogatory treatment of the work. However, such rights are not applicable to publication in a 'newspaper, magazine or similar periodical'. It is unclear whether a learned journal would be classed as a 'similar periodical'.

If publishers have assumed that learned journals are similar, it may explain why this analysis found that the majority of agreements (82.5\% representing $5586(76.5 \%)$ journal titles) did not consider this issue. Those agreements that did consider it approached the protection of an author's moral rights in two main ways. They either gave authors the option of asserting their moral rights (in UK law, some moral rights are only valid if they are asserted by the author), or they simply pledged to honour moral rights. Whether explicitly stated in national copyright law or not, the right to be recognised as the author of the work and to object to derogatory treatment are high on any author's agenda. As publishers see themselves with a copyright protection role, it should please their authors if they made reference to this in their agreements.

\section{Proprietary rights}

Journal articles are protected by copyright, as opposed to trade marks, patents or design rights. However, journal articles may describe patentable ideas or designs and may incorporate trade marks. 
We found that $40 \%$ of the analysed agreements (representing 3.993 journal titles $-54.6 \%$ ) explicitly left proprietary rights with the author. In most cases, this was simply for clarity and the avoidance of doubt. If copyright assignment forms are clearly worded, it should be apparent that other proprietary rights are not being transferred.

\section{Author warranties and undertakings}

In addition to the copyright assignment or licence statement, agreements require authors to make certain warranties to publishers with respect to their work. Eleven warranties or commitments were found in the agreements. Some of these had areas of overlap, but each was considered a distinct area of consideration.

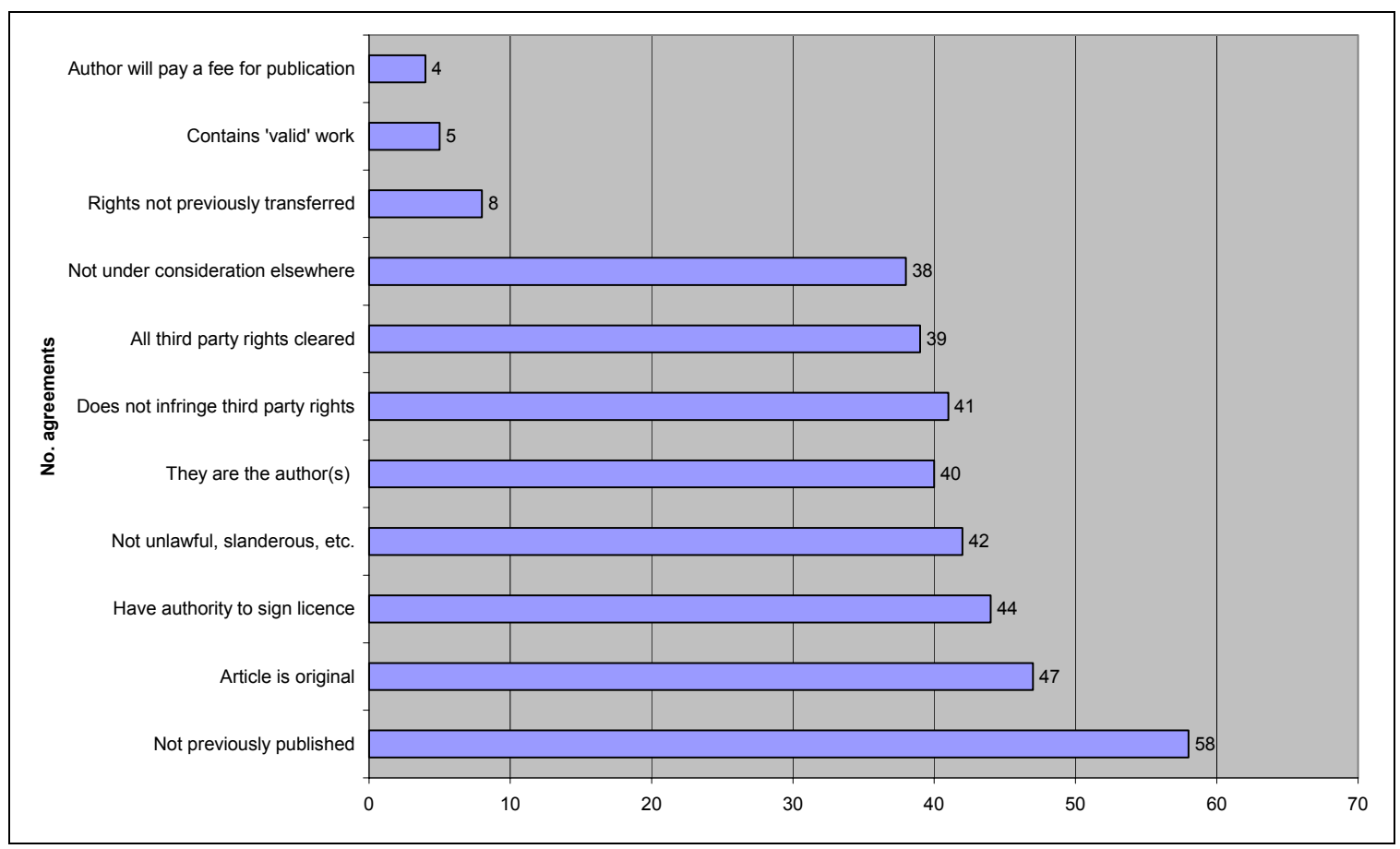

Figure 5 Warranties or commitments required of authors

Figure 5 shows that the most common warranty required of authors was that the work had not been previously published - the so-called Ingelfinger rule ${ }^{21}, 22$. In total, $72.5 \%$ of agreements specified this. Only two agreements were explicit that self-archived web versions of the work were, or may be, considered to be prior publication. Nearly half of the agreements $(47.5 \%)$ asked authors to confirm that the work was not under consideration for publication elsewhere.

The success of the self-archiving initiative depends to some extent on the meaning of 'prior publication' to publishers. To most academics, 'publication' means formal publication in a recognised peer-reviewed vehicle. However, in most debates publishers' have adopted a broader dictionary definition of 'publication" ${ }^{23}$, such as, "the act or an instance of making information public. ${ }^{24}$ " The difference between the two views is, of course, the difference between the raw manuscript or preprint, and the value-added post-print. A report by Frankel et al to the International Association of STM Publishers drew a distinction between 'first publication' (the preprint) and 'definitive publication' (the post-print). It is arguable that academics see self-archiving as communication, and journal publishing as publication.

Where publishers do prohibit prior publication, authors that have already self-archived their preprint have two options. They either sign to say the item has not been previously published (in their 
interpretation of 'published') and risk breach of contract later on, or they amend the assignment form and/or discuss the matter with the publisher, and risk not being published. They may be asked to remove the preprint prior to formal publication. Authors that have not self-archived a preprint, can sign freely, but might need to try to negotiate the rights to self-archive the post-print later on.

The second most frequent warranty was that the work was 'original' (58.7\%). No agreements defined the term 'original' (although a very small number used the phrase 'original with the author') and fewer $(50 \%)$ asked authors to warrant that they were in fact the creator of the work. Some agreements asked all authors to warrant that they had made a significant enough contribution for it to be attributed to them. In consideration of the fact that authors are not always the owner of copyright, $55 \%$ of agreements asked them to warrant that they had the authority to sign the agreement.

However, fifteen agreements that required warranties of authorship omitted to ask whether the author in fact had the right to sign. Very few agreements (10\%) asked that rights had not previously been transferred.

Similar numbers asked authors to confirm that either the article did not infringe third-party rights or that all third-party rights had been cleared. Although these warranties seem similar, into the latter category fell statements relating to copyright permissions for reproducing others' work, whereas the former category contained statements relating to ownership of the submitted work.

In $52.5 \%$ of agreements, the author had to warrant that the article contained no unlawful, libellous, or slanderous material. A very small number of publishers asked authors to give other warranties regarding the quality of the submitted work, although one publisher required the undertaking that the work "contains an important scientific discovery". Another required a statement that "proper reference is made to the preceding literature on this topic". Only four agreements expected authors to pay a fee for publication - usually page charges or for graphics or colour illustrations.

Surprisingly, only 15 publishers (18.7\%) asked authors to indemnify them in respect of their warranties. Publishers not requiring an indemnity may have no recourse to compensation should the warranty prove to be untrue.

\section{Publisher undertakings}

Only one of the eighty agreements examined took the form of a two-way contract outlining the undertakings and responsibilities of both parties. Relatively few gave assurances from the publishers as to what they would do, other than publish, in return for copyright assignment. 


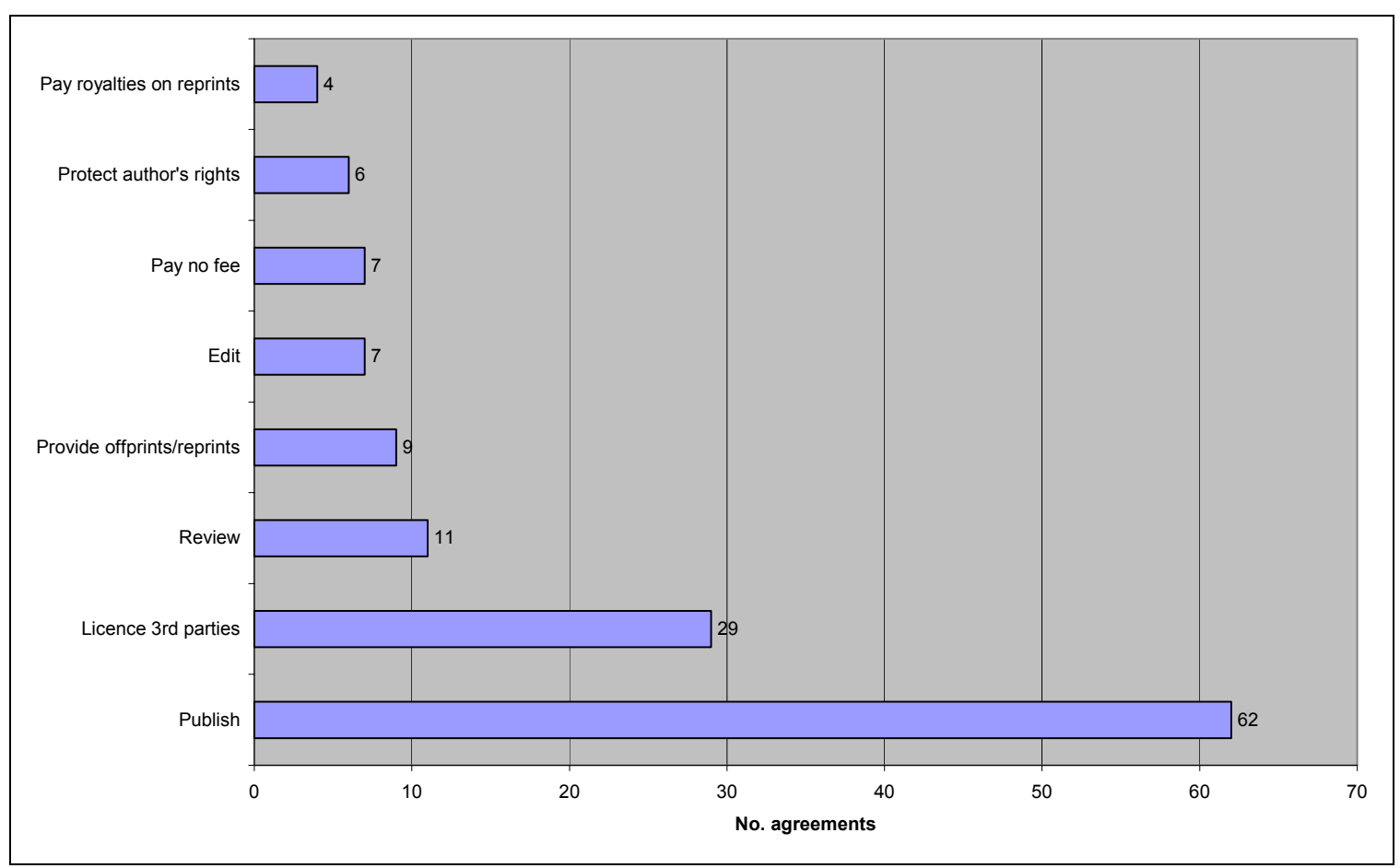

Figure 6 Publisher undertakings

It would be timely to reiterate that this analysis only covers what is explicitly written in the copyright agreement or licence. Thus, although only 62 publishers specified that they intended to publish the paper (subject to successful review), it does not mean that the remaining 18 had no such intention. This must almost certainly be the case with the commitment to review (11 agreements) and edit ( 7 agreements) the submitted works. Twenty-nine publishers specified that they would license third-parties to re-use the work; 16 of these would only do so with the author's consent. Whilst this may benefit the author in terms of increased dissemination, it also protects the publisher's right to a secondary income-stream.

Just nine agreements stated that they would provide the author(s) with a published copy of their work either through offprints, reprints, or a copy of the journal (only one offered a publisher pdf, but for a fee). However, five of these did so only within limits. Two offered a single copy of the journal issue. Two provided 25 free offprints, but only on request, and subsequent copies had to be paid for. One publisher offered 100 reprints, but only if the author paid the 'page-charge' in order to get published in the first place.

Four publishers offered authors a royalty on third-party offprint orders of a certain value. One publisher's exclusive licence (not listed on Figure 6) offered the authors a one-off $\$ 10$ fee in exchange for the licensed rights. However, seven publishers made it explicit that the authors would receive no monetary consideration for their copyright transfer.

\section{Number of agreements offering authors usage rights}

The agreements were studied to see what provisions were made for authors to use their own works once copyright had been assigned or licenced. For the three non-exclusive licences this part of the analysis was not applicable because authors may make unlimited use of their work having only granted such a licence. Of the remaining 77 agreements, $22(28.5 \%)$ representing 651 journal titles $(8.9 \%)$ made no provision for authors to use their own works. Such authors would have to seek the publisher's permission for any use beyond that permitted in national copyright law. Academic authors are often unaware of the implications of this until they come to ask their Librarian to make 
multiple copies of their own paper for their students, and are refused. In most cases, publishers will not refuse (or charge) their authors the permission to make copies, but they have to make a specific application each time they wish to do so.

Three agreements (4\%) representing 122 titles $(1.6 \%)$ were at the other end of the spectrum and allowed authors unlimited usage rights with their own works. The remaining 52 agreements $(67 \%)$ allowed limited usage rights.

\section{Types of usage rights}

Eleven different types of usage rights were identified. Some agreements stated that they would allow authors to use their work in a certain way, but only if the publisher's permission was sought. Such allowances were not considered true usage rights and were omitted from this analysis. The number of agreements listing the various rights is illustrated in Figure 7.

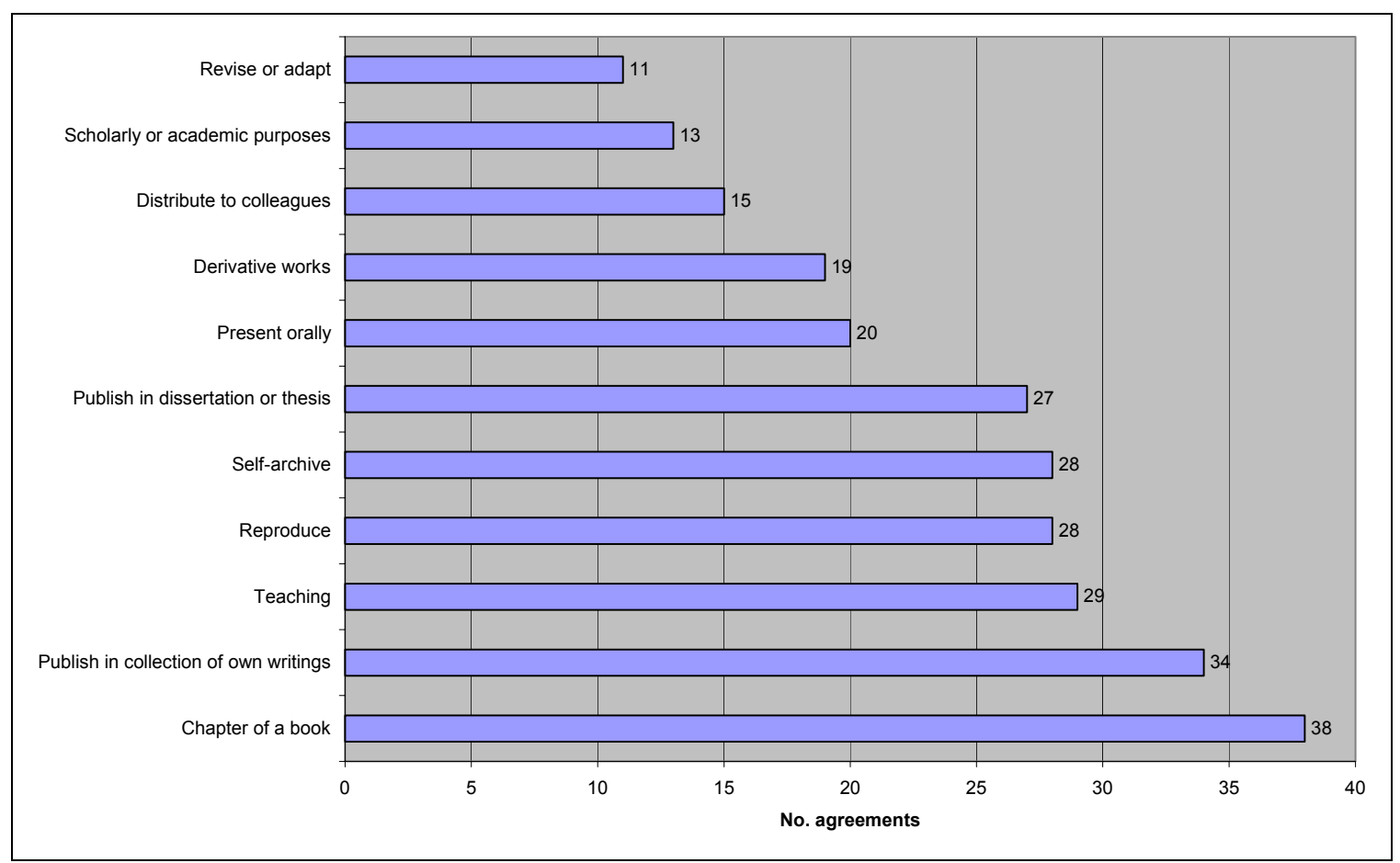

Figure 7 Authors rights of use

Of the 52 agreements allowing limited usage rights, 36 allowed authors to reuse their article as a chapter of a book (69.2\%). Slightly fewer (34) specified that the book must be a collection of the author's own writings. Fewer again (27), specified that the work could be used in a dissertation or thesis. Teaching and general 'reproduction' were allowed by 29 and 28 agreements respectively, although 'distribution to colleagues' and uses for 'scholarly or academic purposes' were mentioned by far fewer (15 and 13).

Self-archiving (making the work available on a freely-accessible web server, not just on an intranet) was permitted by 28 agreements. Including the three non-exclusive licences and the three unlimited exceptions, a total $42.5 \%$ of the agreements overall allowed self-archiving. These agreements represented approximately 3,590 journal titles $-49.1 \%$ of the total represented by this survey. A further four agreements were unclear on this point and may have allowed self-archiving if clarification was sought. They used ambiguous phrases such as "authors need not seek permission to use their own materials in other publications appearing under their own name". It was not clear whether that included freely available web-based publications. 
Twenty agreements allowed authors to present their paper orally. Nineteen explicitly permitted the creation of derivative works, and eleven allowed revisions or adaptations.

\section{A comparison with usage rights required by authors}

The 2002 ALPSP survey asked authors about the importance of various copyright licence usage rights offered by publishers ${ }^{25}$. The results are compared to the usage rights offered by publishers, as found by this analysis, in Table 1 .

\begin{tabular}{|l|c|l|c|}
\hline $\begin{array}{l}\text { Usage rights required } \\
\text { by authors }\end{array}$ & $\begin{array}{l}\text { \% of ALPSP } \\
\text { respondents } \\
\text { ranking right } \\
\text { as 'very } \\
\text { important' }\end{array}$ & $\begin{array}{l}\text { Usage rights offered } \\
\text { by publishers }\end{array}$ & $\begin{array}{l}\text { \% of all CAs } \\
\text { analysed by } \\
\text { RoMEO s * }\end{array}$ \\
\hline $\begin{array}{l}\text { Reuse for educational } \\
\text { purposes }\end{array}$ & $57 \%$ & Reuse for teaching & $43.7 \%$ \\
\cline { 2 - 4 } & $\begin{array}{l}\text { Reuse for scholarly or } \\
\text { academic purposes }\end{array}$ & $23.7 \%$ \\
\hline Use in coursepacks & $32 \%$ & As above & $42.5 \%$ \\
\hline $\begin{array}{l}\text { Put on own/ institution } \\
\text { web site }\end{array}$ & $22 \%$ & Self-archiving & $10 \%$ \\
\hline \multirow{2}{*}{$\begin{array}{l}\text { Right to retain copyright } \\
\text { Reuse in their } \\
\text { publications }\end{array}$} & $21 \%$ & $\begin{array}{l}\text { Exclusive or non- } \\
\text { exclusive licences }\end{array}$ & Reuse in book chapter \\
\cline { 2 - 4 } & & $\begin{array}{l}\text { Publish in collection of } \\
\text { own writings }\end{array}$ & $55 \%$ \\
\cline { 3 - 4 } & & $\begin{array}{l}\text { Publish in } \\
\text { dissertation/thesis }\end{array}$ & $51.25 \%$ \\
\hline
\end{tabular}

Table 1 Comparison of exceptions valued by authors and offered by publishers.

*This figure is the percentage of all 80 agreements including exclusive licences, and those offering no, some, and unlimited exceptions.

The most common usage right offered by publishers - to reuse the work in a book chapter (55\%), was the least highly valued exception by authors $(21 \%)$. The most valued exception to authors: reuse for educational purposes (57\%), was offered by $43.7 \%$ of agreements.

Interestingly, whilst only $32 \%$ of authors stated an interest in mounting an article on their own or institutional web site, $42.5 \%$ of agreements analysed allowed this. However, as mentioned above, statistics in other sections of the report showed that authors' thought the ability to self-archive the postprint online was important to them. Indeed, $12 \%$ of respondents said they would ignore publishers' policies forbidding them from making articles freely available online. Some work done by Pinfield on physicists' use of ArXiv corroborates this ${ }^{26}$. In general though, the practice of selfarchiving is still restricted to certain sub-disciplines within academia - a point underlined by the ALPSP report and much bemoaned by the open-access community ${ }^{27}$.

It was interesting to note that the right to retain copyright ranked lower in the ALPSP survey than any other right, bar the right to re-use a work in another publication. This conflicts with the finding of the 1999 ALPSP survey that showed that " $61 \%$ of respondents thought that copyright should remain with the author, 28 . 


\section{Conditions for general author use}

Nine conditions were identified relating to general usage rights. A different set of conditions applied to self-archiving. These are outlined below. Figure 8 illustrates the number of agreements offering each condition.

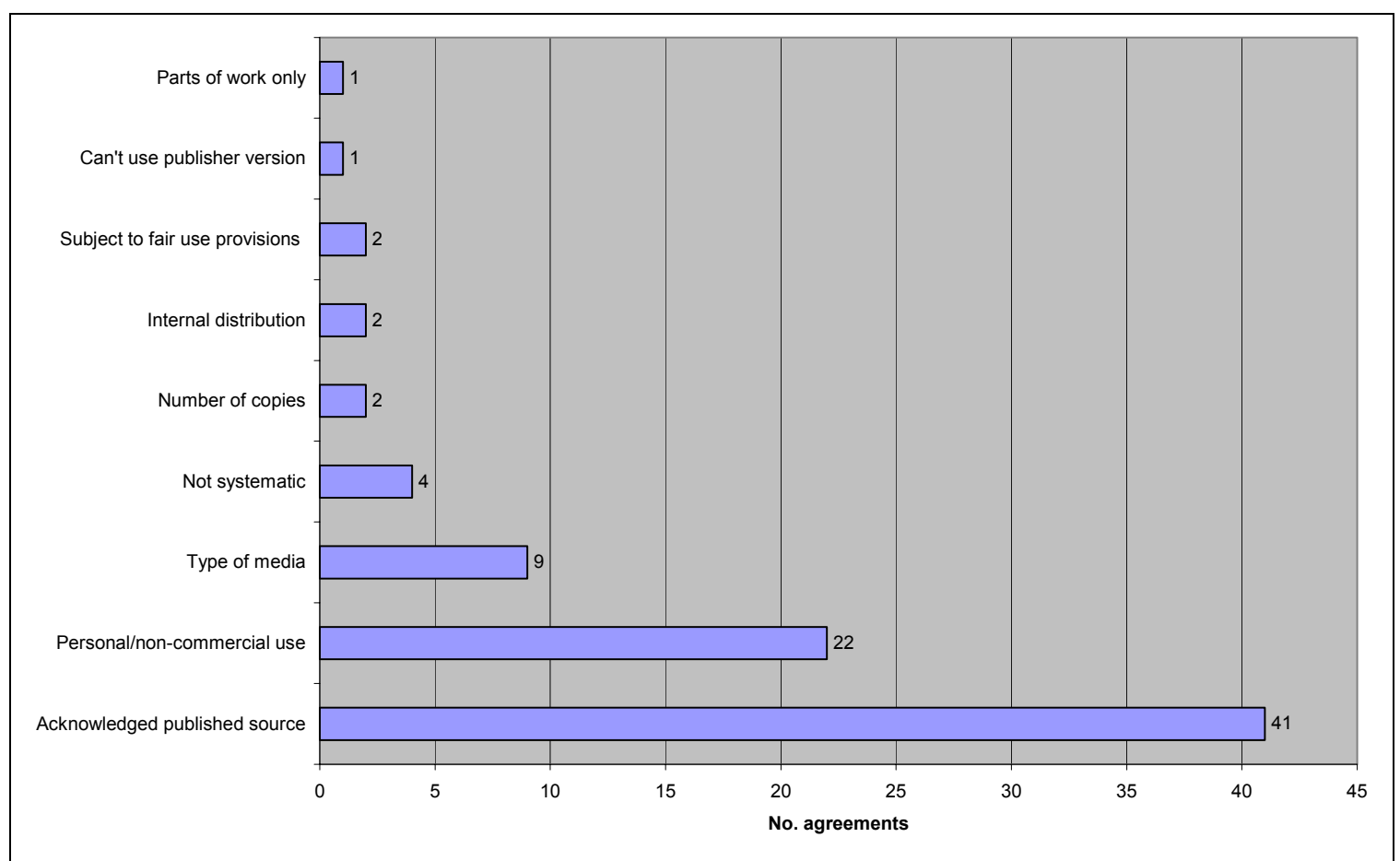

Figure 8 Conditions placed over general usage rights

Forty-one of the 55 agreements (74.5\%) allowing usage rights (either limited or unlimited) asked that the published source be acknowledged on any reproductions. This might take the form of a set copyright statement, or just a bibliographic reference. About half this number (22) stated that usage of the work must be personal or non-commercial. Nine specified that reproductions must be in print as opposed to digital, and in a similar vein, four stated that distribution of the work must not be systematic - for example, by email. The remaining conditions applied only to one or two agreements.

\section{Self-archiving conditions}

The thirty-one agreements allowing self-archiving (including the three non-exclusive licences) did so under the conditions shown in Figure 9. 


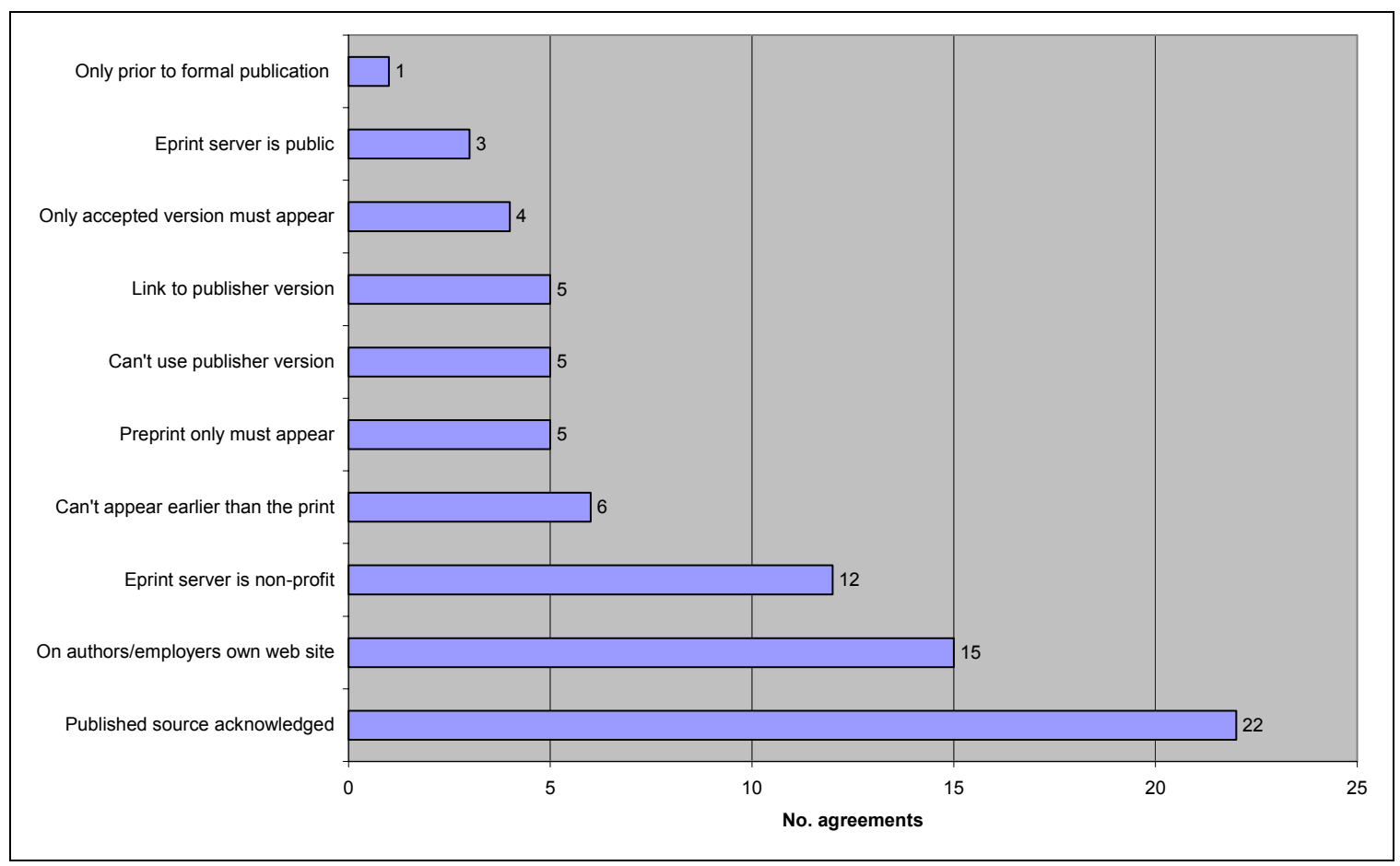

Figure 9 Conditions placed over self-archiving

Again, acknowledging the published source was important to the largest group of publishers (22 or $70.9 \%$ ) and five publishers asked for a link from the self-archived version back to the publisher version. The type of eprint server was important to a good proportion of the publishers and about half would only allow self-archiving on either the author's personal web site or on the institutional site. The motivation for this would appear to be that dissemination of the article is limited to an immediate circle of colleagues and students, thus minimising the potential negative effect on publisher sales. However, under the OAI eprints initiative, it does not matter where the full-text is located, as long as its whereabouts (and related metadata) is widely disseminated by Data Providers and harvested into searchable services by Service Providers. Using personal OAI-compliant software such as Kepler ${ }^{29}$, individuals can also act as OAI Data Providers, thus adhering to publisher requirements but achieving wide dissemination at the same time. Since this analysis, one agreement has been drawn to the authors' attention that specifically, "excludes the enabling or permitting of linking or harvesting of metadata ${ }^{30 "}$. It remains to be seen whether this is the start of a trend.

Timing was also important to publishers - although different views on this emerged. Six said that the eprint cannot appear earlier than the print, one said the eprint must only appear earlier than the print (i.e., it should be removed once the published version was available). Five said that only the preprint (pre-refereed version) must appear, and four said that only the post-print (the accepted version) must appear. Five specified that the publisher version (i.e., the publisher pdf) must not be used for self-archiving (although another said that this was permissible).

Those specifying that only the post-print should appear were presumably concerned to ensure that the formally published version was the only one on the market to avoid versioning problems. The six publishers that wanted the post-print to only appear were probably concerned to retain exclusive rights over the quality-assured post-refereed version as a means of maintaining their role as preservers of the scientific record.

Does it matter? Proponents of open-access would ideally like publishers to allow both to be made available. The publication of preprints allows authors to immediately disseminate, and gain priority 
over, their research. Many welcome this opportunity because getting an article published with a high-impact journal can take years. Preprints also allow peers to discuss and comment on the paper, which may undergo a number of revisions before being submitted to a journal. The publication of post-prints gives everyone access to the quality-assured article - including those from countries or institutions that may not be able to afford a journal subscription.

\section{Conclusions: The author-publisher bargain.}

Whilst the CA is only one manifestation of the author-publisher relationship, it does represent an important and legally binding aspect of that relationship. It is important, therefore, that it reflects the rights and responsibilities of both parties. Publishers are understandably concerned to ensure that the publication of scholarly materials remains profitable. They therefore wish to set terms and conditions in the CA which protect their perceived interests. Unfortunately, this analysis shows that most agreements are somewhat weighted in the interests of publishers. This may be a natural consequence of years of indifference on the part of authors. However, attitudes within academia appear to be changing on this issue.

The trend amongst publishers towards exclusive licences may mislead authors into thinking that they have retained more rights than they actually have, simply by the use of the term 'licence' as opposed to 'transfer' or 'assignment'. This would not be in the interests of publishers as they may find their rights being unwittingly infringed.

Bammel's Guidelines state that "A learned journal is dependent on the articles submitted by authors", and therefore, "publishers must...understand and address the needs of their author community. ${ }^{31}$ " One way of addressing those needs would be to demand only an exclusive licence for "definitive publication" (as defined by Frankel et al's proposal to the International Association of STM Publishers ${ }^{32}$ ) and for a non-exclusive licence to perform any other activity. The US Government clauses in the majority of agreements suggest that publishers could accommodate this.

If a non-exclusive licence is not an option, publishers are encouraged to carefully consider authors' needs as described by the 2002 ALPSP survey and license them the rights to do what they want to do. At the very least, publishers should explicitly grant authors the right to reuse their own works to save both author and publisher the trouble of clearing permission on a case-by-case basis.

However, it is not only authors' own needs that should be considered, but how authors would like others to be able to use their papers. Research by the RoMEO Project has suggested that academic authors are prepared to allow far more liberal usage of their works than either copyright law or most e-journal licences allow ${ }^{33}, 34$.

The balance of rights between authors, universities and publishers has been discussed in great detail in earlier papers in this series ${ }^{35}$ and those arguments will not be rehearsed here. However, the emerging models of scholarly communication suggest that a reshuffling of the roles of each player is likely. As they do so, the issue of copyright transfer will need revisiting. To this end, the Zwolle Copyright and Universities ${ }^{36}$ conferences have performed an important service by facilitating discussions amongst stakeholders to ensure an optimal distribution of rights. We propose that an important aspect of that work should be a revisiting of author-publisher agreements to find an balanced solution that meets the needs of both parties. 


\section{Acknowledgements}

The authors are grateful to the JISC for funding this study, and to Ulrich's International Periodicals Directory for informing the target publisher list. We also acknowledge the helpful and detailed comments of the referees. 


\section{Appendix A - Criteria against which agreements were analysed}

\begin{tabular}{|c|c|}
\hline Main question & Possible options \\
\hline \multicolumn{2}{|l|}{ One or all sign? } \\
\hline What is assigned? (licensed) & (assignment statement) \\
\hline \multicolumn{2}{|l|}{ Exclusive Licence option? } \\
\hline \multirow[t]{3}{*}{ What is kept? } & Paternity rights \\
\hline & Integrity rights \\
\hline & Patents, design or other rights (All proprietary rights other than copyright) \\
\hline When is it assigned? & (pre or post peer review) \\
\hline \multirow[t]{11}{*}{ What is warranted/undertaken? } & They are author (I.e. they've done enough work to warrant being called author) \\
\hline & They can sign licence (I.e. the authority to make the grant) \\
\hline & Rights not previously transferred \\
\hline & Article is original \\
\hline & Not previously published \\
\hline & Doesn't infringe 3rd party rights \\
\hline & All 3rd party rights cleared \\
\hline & No unlawful, slanderous material \\
\hline & Not being reviewed elsewhere \\
\hline & Contains important scientific discovery (or valid work) \\
\hline & Author will pay a fee for publication \\
\hline \multirow[t]{7}{*}{ What author gets in return } & No Fee \\
\hline & Rights protected \\
\hline & Reviewing \\
\hline & Editing \\
\hline & A published copy of their work (e.g. offprints, or journal issue) \\
\hline & Publisher pdf \\
\hline & Royalty \\
\hline \multirow[t]{2}{*}{ What publisher will do } & Publish \\
\hline & Licence 3rd parties to publish \\
\hline \multicolumn{2}{|l|}{ Why is copyright required? } \\
\hline & Reasons \\
\hline \multirow[t]{12}{*}{ Usage rights } & Scholarly or academic purposes \\
\hline & Teaching \\
\hline & Reproduce \\
\hline & Chapter of book etc \\
\hline & revise/adapt \\
\hline & Derivative works \\
\hline & Present orally \\
\hline & Distribute to colleagues \\
\hline & Self-archive \\
\hline & Publish in collection of own writings \\
\hline & Publish in dissertation or thesis \\
\hline & Unlimited exceptions \\
\hline \multirow[t]{7}{*}{ Usage rights conditions } & Copyright notice (or acknowledge pubilshed source) \\
\hline & Type of media \\
\hline & No of copies \\
\hline & Personal/non-commercial use \\
\hline & In print only \\
\hline & Not systematic (e.g. email) \\
\hline & Internal distribution \\
\hline
\end{tabular}




\begin{tabular}{|l|l|}
\hline & Can't use publisher version \\
\hline & Subject to fair use provisions \\
\hline & Parts of work (not whole) \\
\hline Self- archiving conditions & Eprint server is public \\
\hline & Eprint server is non-profit \\
\hline & Can't appear earlier than the print \\
\hline & Only accepted version must appear \\
\hline & Copyright notice OR Published source acknowledged \\
\hline & Preprint only must appear \\
\hline & Can't use publisher version \\
\hline & On authors/employers own web site \\
\hline & On an intranet \\
\hline & Only prior to publication (once published, must be removed) \\
\hline & Link to publisher version \\
\hline Employer ownership & "Work for hire" option? \\
\hline & Less restrictive for employer ownership? \\
\hline & Details of employer licence \\
\hline & US Govt option? \\
\hline & Crown @ option? \\
\hline Other aspects & \\
\hline
\end{tabular}




\section{References}

${ }^{1}$ Bammel, J. (1999). "The publisher-author relationship: principles of good practice in scholarly journal publishing." Learned Publishing 12(2): 75-78.

2 Oliver, R. (1999). "Copyright assignment: some considerations." Learned Publishing 11(1): 4-7.

${ }^{3}$ (1999). What authors want :the ALPSP research study on the motivations and concerns of contributors to learn. West Sussex, Association of Learned and Professional Society Publishers.

${ }^{4}$ Gadd, Elizabeth., Charles Oppenheim and Steve Probets. RoMEO Studies 1: The impact of copyright ownership on author self-archiving. Journal of Documentation 59(3), 243-277.

${ }^{5}$ Swan, A. (2002). Authors and electronic publishing: the ALPSP research study on authors' and readers' views of electronic research communication. West Sussex, ALPSP.

${ }_{7}^{6}$ Project RoMEO. (2003) URL: http://www.lboro.ac.uk/departments/dis/disresearch/romeo/index.html

7 Jaffe, S. (2002). "The next Research Assessment Exercise will probably include citation analysis." The Scientist 16(22): 54.

${ }^{8}$ The market for scientific, technical and medical journals: A statement by the OFT. (2002). London, Office of Fair Trading: 27 URL: http://www.oft.gov.uk/News/Press+releases/2002/PN+55-

$02+$ Can+the+scientific+journals+market+work+better\%3f.htm.

${ }^{9}$ Association of Learned and Professional Society Publishers. URL: http://www.alpsp.org/

${ }^{10}$ Society for Scholarly Publishing. URL: http://www.sspnet.org/

${ }_{11}$ Ulrich's Periodicals Directory Database. Accessed 14 January 2003.

12 Morris, S. (2000). "Guest Editorial. Authors and copyright." Learned Publishing 13(2): 75-76.

${ }^{13}$ ALPSP (1999). Model Grant of Licence. URL: http://www.alpsp.org/grantli.pdf.

${ }^{14}$ See the September-98-Forum list. Threads entitled: "Learned Society Publisher's Comment on

PLoS/Sabo" and "Detecting Plagiarism". 22-23 July, 2003. URL: http://amsci-

forum.amsci.org/archives/september98-forum.html

${ }^{15}$ Lawrence, S. (2001). "Online or invisible?" Nature 411(6837): 521

http://www.neci.nec.com/ lawrence/papers/online-nature01/.

${ }^{16}$ Copyright Law of the United States of America and related laws contained in title 17 of the United States Code. http://www.copyright.gov/title17/circ92.pdf. (2001) Washington, D.C., Library of Congress: US Copyright Office.

${ }^{17}$ BioMed Central's Publishing Model. (2003) URL: http://www.biomedcentral.com/download/advocacy/lib_advocacy.ppt

${ }^{18}$ Harnad, S. (2001). For Whom the Gate Tolls? How and Why to Free the Refereed Research Literature Online Through Author/Institution Self-Archiving, Now. URL:

http://cogprints.soton.ac.uk/documents/disk0/00/00/16/39/index.html.

${ }^{19}$ Kahin, B. (1994). The Copyright law: how it works and new issues in electronic settings. New scholarship: new serials. Proceedings of the North American Serials Interest Group. 8th Annual Conference, June 10-13, 1993. Brown University, Providence, Rl. G. McMillan, and Marilyn Norstedt. New York, Haworth Press: 163172.

${ }^{20}$ Rosenblatt, B. (1998). Moral rights basics, Harvard Law School

http://cyber.law.harvard.edu/property/library/moralprimer.html. 2002.

${ }^{21}$ Relman, A. S. (1981). "The Ingelfinger Rule." New England Journal of Medicine 305(Oct 1, 1981): 824-826.

${ }^{22}$ Angell, M., J.P. Kassirer (1991). "The Ingelfinger rule revisited." New England Journal of Medicine 325(Nov.7, 1991): 1371-1373.

${ }^{23}$ See for example, the September-98-Forum list. Thread entitled: Garfield: "Acknowledged Self-Archiving is Not Prior Publication". 31 August - 13 September, 2002. URL: http://amsci-

forum.amsci.org/archives/september98-forum.html

${ }^{24}$ Hanks, Patrick (ed.) Collins dictionary of the English language. (2nd ed.) London : Collins, 1986.

${ }^{25}$ Swan, A. (2002). Authors and electronic publishing: the ALPSP research study on authors' and readers' views of electronic research communication. West Sussex, ALPSP: 83pp. Pp. 24-25.

${ }^{26}$ Pinfield, S. (2001). "How Do Physicists Use an E-Print Archive? Implications for Institutional E-Print Services." D-Lib Magazine 7(12): http://www.dlib.org/dlib/december01/pinfield/12pinfield.html.

${ }^{27}$ Day, M. (2003). Prospects for institutional e-print repositories in the United Kingdom: ePrints UK supporting study, no. 1. Bath, UKOLN. URL:

http://www.rdn.ac.uk/projects/eprints-uk/docs/studies/impact/.

${ }^{28}$ (1999). What authors want :the ALPSP research study on the motivations and concerns of contributors to learn. London, Association of Learned and Professional Society Publishers.

${ }^{29}$ Maly, K., Mohammad Zubair and Xiaoming Liu (2001). "Kepler - An OAI Data/Service Provider for the Individual." D-Lib Magazine 7(4): http://www.dlib.org/dlib/april01/maly/04maly.html. 
${ }^{30}$ Le Hunte Ward, F. (2003). Metadata and copyright. Post to the metadata@creativecommons.org discussion list. Monday 10 March, 2003

${ }^{31}$ Bammel, J. (1999). "The publisher-author relationship: principles of good practice in scholarly journal publishing." Learned Publishing 12(2): 75-78.

${ }^{32}$ Frankel, Mark S. et al. (2000). "Defining and Certifying Electronic Publication in Science: A Proposal to the International Association of STM Publishers." Learned Publishing 13(4): 251-258.

${ }^{33}$ Gadd, E., Charles Oppenheim and Steve Probets (2003). "RoMEO Studies 2: How academics want to protect their open-access research papers." Journal of Information Science [In Press]

${ }^{34}$ Gadd, E., Charles Oppenheim and Steve Probets (2003). "RoMEO Studies 3: How academics expect to use open-access research papers." Submitted to Journal of Librarianship and Information Science

${ }^{35}$ Gadd, Elizabeth., Charles Oppenheim and Steve Probets. RoMEO Studies 1: The impact of copyright ownership on author self-archiving. Journal of Documentation 59(3), 243-277

${ }^{36}$ Zwolle Group. (2003). The Zwolle approach: balancing stakeholders' interests in scholarship-friendly copyright practices. Report of working conference on Copyright and Universities: from principles to practices, Zwolle, 6 and 7 December 2002. URL: http://www.surf.nl/copyright/zwolle/2002dec/index.php. 